\title{
Intercontinental comparison of ferns community assemblages in Malaysian and Nigerian tropical forests
}

\section{Gbenga F. Akomolafe ${ }^{1,2}$, Rusly Binti Rosazlina ${ }^{1 *}$, Zakaria $\operatorname{Rahmad}^{1}$ and Fatai A. Oloyede $^{3}$}

${ }^{1}$ School of Biological Sciences, Universiti Sains Malaysia, 11800 Penang, Malaysia

${ }^{2}$ Department of Plant Science and Biotechnology, Federal University of Lafia, Nigeria

${ }^{3}$ Department of Botany, Obafemi Awolowo University, Ile-Ife, Nigeria

*Corresponding author: rosazlinarusly@usm.my

\section{Abstract}

Research on ferns ecology has gained attention in the last decade, yet there is paucity of information on the intercontinental comparison of ferns community across two continents. This study focused on comparing the ferns community assemblages in tropical forests of Malaysia and Nigeria, thereby assessing the patterns of the species richness and diversity across the two continents. The diversity and taxonomic compositions of ferns were assessed using 180 plots of size $10 \mathrm{~m} \times 10 \mathrm{~m}$ in each country. The species richness and other diversity indices were determined using the combined forests data for each country and for the individual forests. The observed and rarefied-extrapolated fern species richness are significantly higher in Malaysian forests than Nigerian forests. Also, the other diversity indices (Simpson index, Margalef index, and Fisher's alpha) are significantly higher in Malaysian forests except Shannon index which showed no significant difference between the two biogeographic regions. There is a very low similarity in the taxonomic composition of ferns between the two biogeographic areas, although the similarity in composition increased with increasing taxonomic levels (genus and family levels). Terrestrial and epiphytic ferns are more dominant than the other life forms in the two countries. Since the two countries receive varying degrees of environmental factors, we then 
24 hypothesize that these observed differences are due to climatic differences as well as historical

25 and evolutionary processes.

26 Keywords: ecological zones, ferns diversity, intercontinental, species richness, tropical forests.

\section{Introduction}

28 Pteridophytes (Ferns) are known to be an essential part of the biodiversity and vegetations of

29 tropical forest ecosystems [1]. They originated from the old world tropics and have colonized

30 other regions of the world [2]. Ferns generally constitute the substantial biomass of many

31 tropical and subtropical forests of the world [3]. Their occurrence and abundance in these

32 tropical regions are largely dependent on moisture availability [4]. Apart from their biodiversity

roles in the ecosystems, they are also useful to mankind in diverse ways such as for ornamentals,

34 medicines, and food $[5,6]$. Over the years, there have been several collections of ferns across many tropical forests of Malaysia which have led to the documentation of over 1165 fern species out of the 4400 species reported for South East Asia [7, 8]. Similarly, ferns are known to be

37 found widely across many ecological zones of Nigeria, constituting about 165 species, 64 genera, and 27 families [9]. Although several factors such as unplanned urbanization, farming, and mineral exploitations have threatened their existence in many parts of Nigeria [10].

Malaysia and Nigeria are both located within the tropics, yet they both differ in some climatic conditions. For instance, researches have reported that tropical forests in Africa receive lesser

42 amount of rainfall than the ones of Southeast Asia [11, 12]. In the same vein, the rainfall extends

43 through the year in Southeast Asian tropical forests as compared with that of West Africa forests.

44 This results in a higher relative humidity in Asian tropical forests than in African tropical forests

45 [13]. These climatic differences have caused variations in the floristic composition between the 
46 two regions. There is little information on the ferns differences between Asian and African

47 forests as researchers are more focused on trees, lianas and other plant types [14].

48 Due to the evolutionary and climatic differences of the two continents, single research that

49 assesses floristic data from these two tropical regions can boost our understanding of

50 biogeographic patterns in ferns ecology. Single researches that cover more than one continent are

51 regarded as more effective in drawing the intercontinental patterns of species ecology than

52 individual researches that only focus on one specific continent [14]. Hence, our study focused on

53 determining the intercontinental patterns in ferns community assemblages between Malaysian

54 and Nigerian tropical forests. Consequently, the following questions were asked: (1) does ferns

55 diversity and community structure differs between Malaysian and Nigerian forests? (2) Are there

56 any similarity in the ferns taxonomic composition between Malaysian and Nigerian forests?

\section{Materials and Methods}

\section{Study Area}

59 The study was conducted in some tropical recreational forests and University campuses in

60 Nigeria and Malaysia. In Nigeria, the ferns species were collected from the campus of the

61 Obafemi Awolowo University (OAU), Ile-Ife, Osun State and the reserved forest near Ikogosi

62 warm spring, Ekiti State (Fig. 1). This University campus is located in Ile-Ife which lies between

63 latitude $7^{\circ} 32^{\prime} \mathrm{N}$ and longitude $4^{\circ} 32^{\prime} \mathrm{E}$. The campus was originally sited on a primary forest which

64 has now been transformed into secondary forest due to the level of human encroachments [15].

65 Ile-Ife city falls within the tropical rain forest zone of Nigeria which receives an average annual

66 rainfall of 1400 to $1500 \mathrm{~mm}$ and a mean annual temperature ranging between $27^{\circ} \mathrm{C}$ to $34^{\circ} \mathrm{C}$. The

67 tropical rain forest vegetation is characterized mainly by abundant trees with few woody shrubs. 
Ile-Ife like other cities in Nigeria has two main seasons including the dry and rainy seasons. The city experiences rainy season between March and October whereas it experiences dry season between November and early March [16]. The second site, Ikogosi warm spring forest is located

71 at Ikogosi, Ekiti State. It has a geographical boundary of latitude $7^{\circ} 34^{\prime} \mathrm{N}$ and longitude $4^{\circ} 58^{\prime} \mathrm{E}$.

72 This warm spring has been recognized as a recreational center which houses both primary and 73 secondary forests. One major interesting thing about the warm spring is the confluence point 74 between it and another cold spring. Figure 1: Study area map of Peninsular Malaysia showing USM campus and Bukit Hijau forests. (USM), Penang Island and Bukit Hijau recreational forest, Kedah (Fig. 2). Both sites are located within the Peninsular Malaysia. This peninsular is known to be the floristically richest part of Indomalesian sub-kingdom [17]. This campus is situated on about 252.7 hectares of land. The vegetation comprises extensively large canopy trees. This city has a tropical climate with an average annual rainfall of almost $2670 \mathrm{~mm}$ [18]. Also, it receives a daily temperature range of $24^{\circ} \mathrm{C}$ to $32^{\circ} \mathrm{C}$ and relative humidity of 70 to $90 \%$. The second site which is Bukit Hijau recreational forest is located at $42 \mathrm{~km}$ away from Baling town, Kedah, Peninsular Malaysia. It

84 has a geographic boundary of latitude $5^{\circ} 30^{\prime} \mathrm{N}$ and longitude $100^{\circ} 46^{\prime} \mathrm{E}$ ). This forest was established as a recreational forest in 1959, and it has been used for activities such as picnics, campsites, eco-tourism, and educational activities [7]. The forest has also housed wildlife, such

87 as elephants, tigers, tapirs, monkeys, deer, birds, and squirrels [19]. The forest is characterized above sea level. 
Figure 2: Study area map of Nigeria showing OAU campus and Ikogosi warm spring forest.

91

92

93

\section{Ferns Sampling Technique}

In each site, ferns were sampled at three different areas within the forested areas. This includes the undisturbed area, less-disturbed area and most-disturbed area. These areas were selected based on the observation of the rate of human encroachments and infrastructural developments. The sampling was designed to cover all the three areas. Thirty plots of size $10 \mathrm{~m} \times 10 \mathrm{~m}$ were established in each area, giving rise to a total of 90 plots per site and 180 plots in each country. A preferential non-random method of sampling which ensured that at least one individual fern was captured in each plot, was adopted for the study [9].

In all the established plots, the abundance of individual ferns found were noted and categorized as terrestrial, aquatic, epiphytes and lithophytes. Some of the ferns were identified directly on the field. Those with difficult identification were pressed and identified at the herbaria of Universiti Sains Malaysia and Federal University of Lafia. The fern species were thereafter identified using taxonomic flora $[20,21,22]$ and online database of International Plant Names Index. The voucher specimens were deposited in the respective herbarium depending on the country for references. The conservation status of each identified fern was assessed from the redlist database of the International Union for the Conservation of Nature (IUCN).

\section{Data Analyses}

The relative frequency of each fern species was calculated for the two biogeographic areas. In order to have a considerable comparison of the species richness between the two campuses, a non $\square$ asymptotic rarefaction-extrapolation analysis which is a species richness evaluator was employed [14]. This was done using the individual-based abundance data for each fern species. Significant difference in the rarefied-extrapolated fern species richness between the countries 
113 was determined by the confidence intervals of the species accumulation curves, constructed 114 using 50 bootstrap replicates. This analysis was achieved with the aid of iNEXT software (online 115 version) [23]. An overlap in the confidence intervals of the curves indicates the absence of

116 statistical significance difference between the species richness of the two countries. Significance

117 difference in the species richness is only established when the confidence intervals of the curves

118 are non-overlapping [7]. This analysis is very important as it eradicates bias which is usually

119 encountered in field sampling. The ferns diversity indices such as Shannon index, Simpson index

120 and Margalef index were quantified for each country using paleontological statistics (PAST) 3.0

121 software. Pairwise permutation tests were used to determine the significant differences in the

122 diversity indices between the countries.

123 Sorensen's similarity index was used to determine the intercontinental similarity in the ferns

124 compositions at the three taxonomic levels (species, genus and family) between the two studied

125 areas. The life forms of the ferns were associated with the two countries using a non-metric

126 multidimensional scaling (nMDS) analysis with Bray-Cutis dissimilarity measures with the aid

127 of the PRIMER 7 software. Variations in the distribution of the ferns species across the two 128 continents were determined using the principal component analysis (PCA) of the PAST software.

129 Results and Discussion

130 A total of 54 ferns species were observed in Malaysian forests while total of 27 ferns were 131 observed in Nigerian forests (Table 1). This difference in the ferns species is significant as 132 revealed by the pairwise permutation test $(P=0.001)$. In the same vein, the rarefied-extrapolated 133 species richness shows that the Malaysian forests are richer in ferns than Nigerian forests (Fig. 134 3a). The rarefied and extrapolated species richness curves for both countries reached asymptote 135 showing that there was an adequate sampling of the ferns in the forests. This is also evident by 
136 the equal values of the observed and rarefied-extrapolated species richness of ferns of both

137 countries. All the diversity indices of the combined forests of Malaysia are significantly higher

138 than those of Nigerian forests (pairwise permutation test: $P=0.001$ ) except the Shannon

139 diversity index which showed no significant difference $(P>0.05)$. These trends generally

140 indicated that Malaysian forests are richer and more diverse in fern species than the Nigerian

141 ones. This could be due to the significant roles moisture and other microclimatic conditions play

142 in the occurrence and distribution of ferns in tropical forests [4]. South East Asian countries

143 particularly Malaysia is known to receive more rainfall throughout the year than West African

144 ones $[14,13]$. This may account for the differences in the richness of ferns between the two

145 continents. It is also important to state that the two countries are more diverse in fern species as

146 ecosystems with Shannon index of 2 and above are considered more diverse [24].

147 Figure 3a: Individual-based rarefied-extrapolated species richness curves for the combined

148 forests of both Malaysia and Nigeria.

149 Table 1: comparison of ferns community characteristics between Malaysia and Nigeria

\begin{tabular}{|c|c|c|}
\hline Community Characteristics & Malaysia & Nigeria \\
\hline Total observed species richness* & $54^{\mathrm{a}}$ & $27^{\mathrm{b}}$ \\
\hline $\begin{array}{l}\text { Rarefied and extrapolated species } \\
\text { richness }^{* *}\end{array}$ & $54^{\mathrm{a}}$ & $27^{b}$ \\
\hline Number of individuals & 18004 & 4399 \\
\hline Simpson index ${ }^{*}$ & $0.849^{\mathrm{a}}$ & $0.826^{\mathrm{b}}$ \\
\hline Shannon diversity index ${ }^{*}$ & $2.399^{\mathrm{a}}$ & $2.345^{\mathrm{a}}$ \\
\hline Evenness index* & $0.204^{\mathrm{a}}$ & $0.386^{\mathrm{b}}$ \\
\hline Margalef index* & $5.409^{a}$ & $3.099^{\mathrm{b}}$ \\
\hline Fisher's alpha* & $6.859^{\mathrm{a}}$ & $3.832^{\mathrm{b}}$ \\
\hline
\end{tabular}


150 *Significant differences determined by pairwise permutation tests in PAST.

$151{ }^{* *}$ Significant difference determined by confidence interval of the curves

152

153 As for the individual forests in Malaysia, it was observed that the Bukit Hijau forest has a 154 significantly higher number of ferns (44) than the USM campus forest (23). This trend was also 155 observed in all the diversity indices of the two forests except for the evenness index which 156 showed no significant difference between them (Table 2, Fig. 3b). In Nigeria, OAU campus 157 forest was observed to have a significantly higher number of ferns (24) than Ikogosi warm spring 158 forest (11). The same trend was also observed in all other diversity indices measured except the 159 Simpson index (Table 2, Fig. 3c). These observed differences between the individual forests of 160 each country could be due to other factors than climate. This is because the two study sites in 161 each country are influenced by almost similar climatic conditions with slight differences. The 162 most suspicious factor could be the extent of human disturbances in each forest [9]. For example, 163 the Ikogosi warm spring forest is a recreational forest which receives so many tourists daily with 164 no strict protection of the forest species. The reverse is the case for Bukit Hijau forest which has 165 some measures of protection for its forest species [17].

166 Figure 3b: Individual-based rarefied-extrapolated species richness curves for the individual 167 forests in Malaysia

168 Figure 3c: Individual-based rarefied-extrapolated species richness curves for the individual 169 forests in Nigeria.

170 Table 2: comparison of ferns community characteristics between individual sampling sites in 171 Malaysia and Nigeria 


\begin{tabular}{|c|c|c|}
\hline \multicolumn{3}{|l|}{ Malaysia } \\
\hline Community Characteristics & USM Campus forest & Bukit Hijau forest \\
\hline Total observed species richness ${ }^{*}$ & $23^{\mathrm{a}}$ & $44^{\mathrm{b}}$ \\
\hline $\begin{array}{l}\text { Rarefied and extrapolated species } \\
\text { richness }{ }^{* *}\end{array}$ & $23^{\mathrm{a}}$ & $44^{\mathrm{b}}$ \\
\hline Number of individuals & 7925 & 10079 \\
\hline Simpson index ${ }^{*}$ & $0.762^{\mathrm{a}}$ & $0.874^{\mathrm{b}}$ \\
\hline Shannon diversity index* & $1.828^{\mathrm{a}}$ & $2.517^{\mathrm{b}}$ \\
\hline Evenness index ${ }^{*}$ & $0.271^{\mathrm{a}}$ & $0.282^{\mathrm{a}}$ \\
\hline Margalef index ${ }^{*}$ & $2.450^{\mathrm{a}}$ & $4.665^{b}$ \\
\hline Fisher's alpha* & $2.907^{\mathrm{a}}$ & $5.913^{b}$ \\
\hline \multicolumn{3}{|l|}{ Nigeria } \\
\hline Community Characteristics & OAU Campus forest & $\begin{array}{l}\text { Ikogosi warm spring } \\
\text { forest }\end{array}$ \\
\hline Total observed species richness* & $24^{\mathrm{a}}$ & $11^{\mathrm{b}}$ \\
\hline $\begin{array}{l}\text { Rarefied and extrapolated species } \\
\text { richness }^{* *}\end{array}$ & $24^{\mathrm{a}}$ & $11^{\mathrm{b}}$ \\
\hline Number of individuals & 3327 & 1049 \\
\hline Simpson index ${ }^{*}$ & $0.753^{\mathrm{a}}$ & $0.778^{\mathrm{a}}$ \\
\hline Shannon diversity index ${ }^{*}$ & $2.100^{\mathrm{a}}$ & $1.829^{b}$ \\
\hline Evenness index ${ }^{*}$ & $0.340^{\mathrm{a}}$ & $0.566^{\mathrm{b}}$ \\
\hline Margalef index* & $2.836^{\mathrm{a}}$ & $1.438^{\mathrm{b}}$ \\
\hline Fisher's alpha* & $3.499^{\mathrm{a}}$ & $1.714^{\mathrm{b}}$ \\
\hline
\end{tabular}

$17{ }^{* *}$ Significant difference determined by confidence interval of the curves

175 Generally, terrestrial ferns are the dominant ferns in Malaysian and Nigerian forests having 37

176 and 17 species respectively while aquatic ferns are the least (Table 3 ). The dominant nature of

177 the terrestrial ferns could also be an indicator to the lesser degree of disturbance of the forests in 
178 the two countries when considered on a larger scale. Researchers have confirmed the dominant

179 nature of terrestrial ferns in less-disturbed forests $[15,17,25,26]$. The non-metric

180 multidimensional scaling analysis showed that the Malaysian and Nigerian forests are more

181 associated with terrestrial and epiphytic ferns than the other life forms of ferns (Fig. 4).

182 Table 3: Life forms of the ferns in Malaysia and Nigeria

\begin{tabular}{lll}
\hline Life form & \multicolumn{2}{l}{ Number of species } \\
\cline { 2 - 3 } & Malaysia & Nigeria \\
\hline Aquatic & 2 & 2 \\
Epiphytic & 12 & 8 \\
Lithophytic & 3 & 0 \\
Terrestrial & 37 & 17 \\
\hline
\end{tabular}

184 Figure 4: nMDS showing the association between the ferns life forms and the two countries.

185 It should be noted that some of these identified ferns exhibited more than one life form. For 186 example, Pteris vittata existed as both terrestrial and lithophytic fern while Nephrolepis 187 biserrata existed as both terrestrial and epiphytic fern in Malaysia and Nigeria. Some ferns have 188 also been reported to have the ability to exist in different life forms [27]. The PCA showed that 189 the principal components (PC) 1 and 2 contributed to $93.52 \%$ and $6.48 \%$ of the total variations 190 respectively (Fig. 5). However, Malaysian forests contributed more significantly to the PC 1 and 
191 Nigerian forests contributed to PC 2. This invariably shows that Malaysian forests contributed

192 largely to the overall variations in the fern species. Pyrrosia lanceolata and Drynaria quercifolia

193 were observed to be the ferns with the highest relative frequencies of $25.36 \%$ and $24.59 \%$

194 respectively in the combined forests of Malaysia (Table 4). In Nigeria, Pneumatopteris afra with

195 the relative frequency of $35.62 \%$ was observed to be the highest.

196 Figure 5: Principal component analysis showing the variations in the distribution of fern species

197 in the two countries. 
Table 4: The distribution of ferns observed in the study areas

\begin{tabular}{|c|c|c|c|c|c|c|}
\hline \multirow[t]{3}{*}{$\mathrm{S} / \mathrm{N}$} & \multirow[t]{3}{*}{ Name of fern } & \multirow[t]{3}{*}{ Family } & \multicolumn{4}{|l|}{ Countries } \\
\hline & & & Malaysia & & Nigeria & \\
\hline & & & $\begin{array}{l}\text { Presence/ } \\
\text { absence }\end{array}$ & $\begin{array}{l}\text { Relative } \\
\text { frequency } \\
(\%)\end{array}$ & $\begin{array}{l}\text { Presence/a } \\
\text { bsence }\end{array}$ & $\begin{array}{l}\text { Relative } \\
\text { frequency } \\
(\%)\end{array}$ \\
\hline 1 & Acrosticum aureum & Pteridaceae & $\sqrt{ }$ & 0.24 & $\mathrm{X}$ & 0 \\
\hline 2 & Adiantum capillus-veneriis & Adiantaceae & $\mathrm{X}$ & 0 & $\sqrt{ }$ & 0.27 \\
\hline 3 & Adiantum latifolium & Adiantaceae & $\sqrt{ }$ & 0.03 & $X$ & 0 \\
\hline 4 & Angiopteris angustifolia & Marattiaceae & $\sqrt{ }$ & 0.12 & $\mathrm{X}$ & 0 \\
\hline 5 & Angiopteris evecta & Marattiaceae & $\sqrt{ }$ & 0.09 & $\mathrm{X}$ & 0 \\
\hline 6 & Asplenium batuense & Aspleniaceae & $\sqrt{ }$ & 0.089 & $\mathrm{X}$ & 0 \\
\hline 7 & Asplenium nidus & Aspleniaceae & $\sqrt{ }$ & 1.87 & $\mathrm{X}$ & 0 \\
\hline 8 & Asplenium scolopendria & Aspleniaceae & $\mathrm{X}$ & 0 & $\sqrt{ }$ & 0.97 \\
\hline 9 & Asplenium scortechinii & Aspleniaceae & $\sqrt{ }$ & 0.13 & $\mathrm{X}$ & 0 \\
\hline 10 & Asplenium trichomanes & Aspleniaceae & $\mathrm{X}$ & 0 & $\sqrt{ }$ & 0.97 \\
\hline 11 & Bolbitis virens & Lomariopsidaceae & $\mathrm{X}$ & 0.16 & $\mathrm{X}$ & 0 \\
\hline 12 & Bolbitis gemmifera & Lomariopsidaceae & $\mathrm{X}$ & 0 & $\sqrt{ }$ & 1.20 \\
\hline 13 & Ceratopteris cornuta & Parkiaraceae & $\mathrm{X}$ & 0 & $\sqrt{ }$ & 0.52 \\
\hline
\end{tabular}




\begin{tabular}{|c|c|c|c|c|c|c|}
\hline 14 & Cyathea contaminans & Cyatheaceae & $\sqrt{ }$ & 0.09 & $\mathrm{X}$ & 0 \\
\hline 15 & Cyathea moluccana & Cyatheaceae & $\sqrt{ }$ & 0.18 & $\mathrm{X}$ & 0 \\
\hline 16 & Cyclosorus ecallosa & Thelipteridaceae & $\sqrt{ }$ & 0.13 & $\mathrm{X}$ & 0 \\
\hline 17 & Cyclopeltis crenata & Aspidiaceae & $\sqrt{ }$ & 0.07 & $\mathrm{X}$ & 0 \\
\hline 18 & Davallia denticulata & Davalliaceae & $\sqrt{ }$ & 3.89 & $\mathrm{X}$ & 0 \\
\hline 19 & Drymoglossum piloselloides & Polypodiaceae & $\sqrt{ }$ & 4.53 & $\mathrm{X}$ & 0 \\
\hline 20 & Drynaria quercifolia & Polypodiaceae & $\sqrt{ }$ & 24.59 & $\mathrm{X}$ & 0 \\
\hline 21 & Drynaria rigidula & Polypodiaceae & $\sqrt{ }$ & 0.19 & $\mathrm{X}$ & 0 \\
\hline 22 & Drynaria sparsisora & Polypodiaceae & $\sqrt{ }$ & 0.31 & $\mathrm{X}$ & 0 \\
\hline 23 & Elaphoglossum callifolium & Lomariopsidaceae & $\sqrt{ }$ & 0.06 & $\mathrm{X}$ & 0 \\
\hline 24 & Gleichenia linearis & Gleicheniaceae & $\mathrm{X}$ & 0 & $\sqrt{ }$ & 1.79 \\
\hline 25 & Gleichenia truncata & Gleicheniaceae & $\sqrt{ }$ & 7.53 & $\mathrm{X}$ & 0 \\
\hline 26 & Goniophlebium verrucosum & Polypodiaceae & $\sqrt{ }$ & 0.07 & $\mathrm{X}$ & 0 \\
\hline 27 & Hymenophyllum acanthoides & Hymenophyllaceae & $\sqrt{ }$ & 0.05 & $\mathrm{X}$ & 0 \\
\hline 28 & Hymenophyllum productum & Hymenophyllaceae & $\sqrt{ }$ & 0.06 & $\mathrm{X}$ & 0 \\
\hline 29 & Lepisorus longifolius & Polypodiaceae & $\sqrt{ }$ & 0.03 & $\mathrm{X}$ & 0 \\
\hline 30 & Lindsaea lucida & Lindsaeaceae & $\sqrt{ }$ & 1.29 & $\mathrm{X}$ & 0 \\
\hline
\end{tabular}




\begin{tabular}{|c|c|c|c|c|c|c|}
\hline 31 & Lindsaea napaea & Lindsaeaceae & $\sqrt{ }$ & 8.18 & $\mathrm{X}$ & 0 \\
\hline 32 & Lygodium circinnatum & Schizaeaceae & $\sqrt{ }$ & 0.05 & $\mathrm{X}$ & 0 \\
\hline 33 & Lygodium longifolium & Schizaeaceae & $\sqrt{ }$ & 9.28 & $\mathrm{X}$ & 0 \\
\hline 34 & Lygodium japonicum & Schizaeaceae & $\mathrm{X}$ & 0 & $\sqrt{ }$ & 3.05 \\
\hline 35 & Lygodium microphyllum & Schizaeaceae & $\mathrm{X}$ & 0 & $\sqrt{ }$ & 4.00 \\
\hline 36 & Merinthosorus drynarioides & Polypodiaceae & $\sqrt{ }$ & 0.25 & $\mathrm{X}$ & 0 \\
\hline 37 & Microgramma oweriensis & Polypodiaceae & $\mathrm{X}$ & 0 & $\sqrt{ }$ & 1.00 \\
\hline 38 & Nephrolepis acutifolia & Nephrolepidaceae & $\sqrt{ }$ & 0.74 & $\mathrm{X}$ & 0 \\
\hline 39 & Nephrolepis biserrata & Nephrolepidaceae & $\sqrt{ }$ & 1.76 & $\sqrt{ }$ & 14.52 \\
\hline 40 & Nephrolepis cordifolia & Nephrolepidaceae & $\mathrm{X}$ & 0 & $\sqrt{ }$ & 1.77 \\
\hline 41 & Nephrolepis dicksonioides & Nephrolepidaceae & $\sqrt{ }$ & 0.25 & $\mathrm{X}$ & 0 \\
\hline 42 & Nephrolepis duffii & Nephrolepidaceae & $X$ & 0 & $\sqrt{ }$ & 0.97 \\
\hline 43 & Nephrolepis exalta & Nephrolepidaceae & $\mathrm{X}$ & 0 & $\sqrt{ }$ & 1.52 \\
\hline 44 & Nephrolepis furcans & Nephrolepidaceae & $\mathrm{X}$ & 0 & $\sqrt{ }$ & 0.14 \\
\hline 45 & Nephrolepis tuberosa & Nephrolepidaceae & $\sqrt{ }$ & 0.18 & $\mathrm{X}$ & 0 \\
\hline 46 & Nephrolepis undulata & Nephrolepidaceae & $\mathrm{X}$ & 0 & $\sqrt{ }$ & 13.12 \\
\hline 47 & Orthiopteris kingii & Dennstaedtiaceae & $\sqrt{ }$ & 0.07 & $\mathrm{X}$ & 0 \\
\hline
\end{tabular}




\begin{tabular}{lllllll}
\hline 48 & Phymatodes scolopendria & Polypodiaceae & $\mathrm{X}$ & 0 & $\sqrt{ }$ & 0.57 \\
49 & Phymatosorus nigrescens & Polypodiaceae & $\sqrt{ }$ & 0.04 & $\mathrm{X}$ & 0 \\
50 & Pityrogramma calomenalos & Hemionitidaceae & $\sqrt{ }$ & 0.69 & $\sqrt{ }$ & 2.23 \\
51 & Platycerium angolense & Polypodiaceae & $\mathrm{X}$ & 0 & $\sqrt{ }$ & 1.20 \\
52 & Platycerium coronatum & Polypodiaceae & $\sqrt{ }$ & 0.11 & $\mathrm{X}$ & 0 \\
53 & Platycerium stemaria & Polypodiaceae & $\mathrm{X}$ & 0 & $\sqrt{ }$ & 0.79 \\
54 & Pneumatopteris afra & Thelypteridaceae & $\mathrm{X}$ & 0 & $\sqrt{ }$ & 35.62 \\
55 & Pneumatopteris truncata & Thelypteridaceae & $\sqrt{ }$ & 0.13 & $\mathrm{X}$ & 0 \\
56 & Pronephrium asperum & Thelipteridaceae & $\sqrt{ }$ & 0.08 & $\mathrm{X}$ & 0 \\
57 & Pronephrium menisciicarpon & Thelipteridaceae & $\sqrt{ }$ & 0.34 & $\mathrm{X}$ & 0 \\
58 & Pronephrium salicifolium & Thelipteridaceae & $\sqrt{ }$ & 0.19 & $\mathrm{X}$ & 0 \\
59 & Pronephrium triphyllum & Thelipteridaceae & $\sqrt{ }$ & 0.29 & $\mathrm{X}$ & 0 \\
60 & Pteridium aquilinum & Hypolepidaceae & $\mathrm{X}$ & 0 & $\sqrt{ }$ \\
61 & Pteris acanthoneura & Pteridaceae & $\mathrm{X}$ & 0 & $\sqrt{ }$ & 1.20 \\
62 & Pteris artrovirens & Pteridaceae & $\mathrm{X}$ & 0 & $\sqrt{ }$ & 0.77 \\
63 & Pteris burtoni & Pteridaceae & $\mathrm{X}$ & 0 & $\sqrt{ }$ & 1.50 \\
64 & Pteris mildbraedii & Pteridaceae & $\mathrm{X}$ & 0 & $\sqrt{ }$ & 0.50 \\
\hline
\end{tabular}




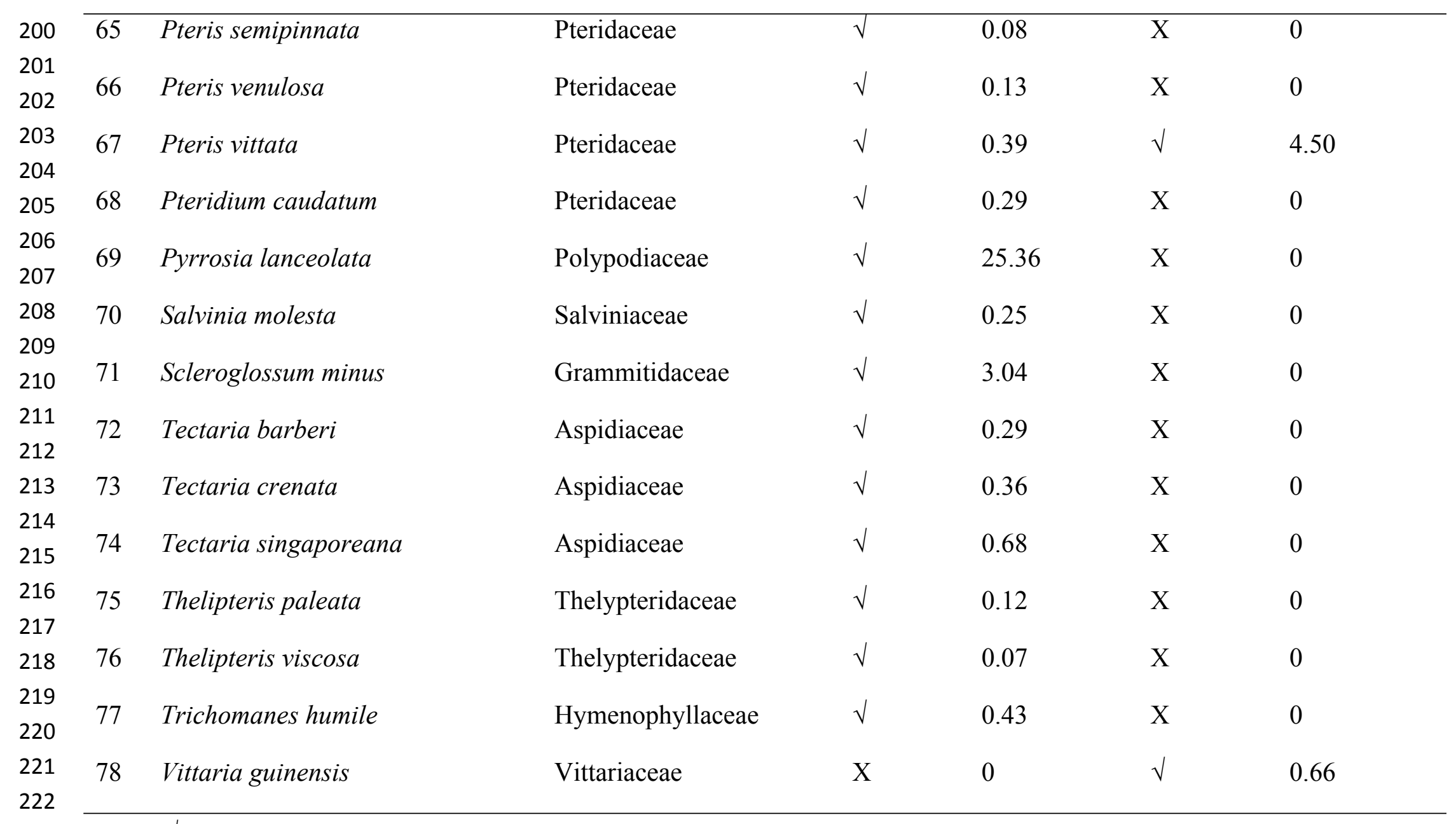

223 KEY: $\sqrt{ }$ means present, $X$ means absent 
224 The common fern species shared by the two countries include Nephrolepis biserrata,

225 Pityrogramma calomelanos, and Pteris vittata. This makes the Sorenson similarity index of the

226 fern species between the two countries to be $7.41 \%$. This is a very low index of similarity which

227 indicates that the two countries, though within the tropics, do not share many fern species in

228 common. This may be due to differences in their evolutionary or historical processes, plus

229 climatic factors of the two regions [28]. However, the similarity in the ferns composition

230 between the two countries increased as the taxonomic level increased (species: $7.41 \%$, genus:

231 12.77\%, family: 70.96\%). The family Polypodiaceae represented by seven genera and nine

232 species is the dominant family of ferns in Malaysia whereas Nephrolepidaceae represented by

233 one genus and six species is the dominant family in Nigeria (Table 5). The dominance of the

234 family Polypodiaceae in Peninsular Malaysia has also been reported by previous studies [17, 7].

236 Table 5: Checklist of families with respective numbers of general and species

\begin{tabular}{llllll}
\hline S/N & Family & \multicolumn{2}{c}{ Malaysia } & \multicolumn{2}{c}{ Nigeria } \\
\hline & & $\begin{array}{c}\text { Number of } \\
\text { Genera }\end{array}$ & $\begin{array}{c}\text { Number of } \\
\text { Species }\end{array}$ & $\begin{array}{c}\text { Number of } \\
\text { Genera }\end{array}$ & $\begin{array}{c}\text { Number of } \\
\text { Species }\end{array}$ \\
\cline { 3 - 6 } 1 & Adiantaceae & 1 & 1 & 1 & 1 \\
2 & Aspleniaceae & 1 & 3 & 1 & 2 \\
3 & Aspidiaceae & 2 & 4 & 0 & 0 \\
4 & Cyatheaceae & 1 & 2 & 0 & 0 \\
5 & Davalliaceae & 1 & 1 & 0 & 0 \\
6 & Dennstaedtiaceae & 1 & 1 & 0 & 0 \\
7 & Gleicheniaceae & 1 & 1 & 1 & 1 \\
\hline
\end{tabular}




\begin{tabular}{llllll}
\hline 8 & Grammitidaceae & 1 & 1 & 0 & 0 \\
9 & Hemionitidaceae & 1 & 1 & 1 & 1 \\
10 & Hymenophyllaceae & 2 & 3 & 0 & 0 \\
11 & Hypolepidaceae & 0 & 0 & 1 & 1 \\
12 & Lindsaeaceae & 1 & 2 & 0 & 0 \\
13 & Lomariopsidaceae & 2 & 3 & 1 & 1 \\
14 & Marattiaceae & 1 & 2 & 0 & 0 \\
15 & Nephrolepidaceae & 1 & 4 & 1 & 6 \\
16 & Parkiaraceae & 0 & 0 & 1 & 1 \\
17 & Polypodiaceae & 7 & 9 & 3 & 4 \\
18 & Pteridaceae & 2 & 5 & 1 & 5 \\
19 & Salviniaceae & 1 & 1 & 0 & 0 \\
20 & Schizaeaceae & 1 & 2 & 1 & 2 \\
21 & Thelypteridaceae & 4 & 8 & 1 & 1 \\
22 & Vittariaceae & 0 & 0 & 1 & 1 \\
\hline
\end{tabular}

239 The results of this study indicated that the Malaysian forests provide favourable microclimatic 240 conditions which supported significantly higher ferns diversity and richness than Nigerian 241 forests. There are distinct differences in the ferns community composition between the two 242 countries which led to a very low similarity index at the species and genus levels. These 243 observed differences in the species composition may be explained by differences in climatic and 244 edaphic factors, as well as historical, and evolutionary processes between the two biogeographic 245 areas. We thereby recommend that future researches should include forests of other countries to 
246 have a robust comparison of variations in ferns community assemblages between Asia

247 and Africa.

248 Acknowledgement

249 The authors hereby acknowledge the Universiti Sains Malaysia for creating enabling 250 environment and for the financial support towards the success of this research.

\section{REFERENCES}

252 [1] Haque AK, Khan SA, Uddin SN, Rahim MA. Taxonomic checklist of the pteridophytes of

253 Rajkandi Reserve Forest, Moulvibazar, Bangladesh. Jahangirnagar Uni J Bio Sci. 2016;5(2): 27-

25440.

255 [2] Mehltreter K, Walker LR, Sharpe JM, editors. Fern ecology. Cambridge University Press; 2562010.

257 [3] Yusuf UK. Ferns of Malaysian rain forest: a journey through the fern world/Professor Dr.

258 Umi Kalsom Yusuf. Serdang, Selangor: Universiti Putra Malaysia Press; 2010.

259 [4] Dixit RD. Conspectus of Pteridophytic diversity in India. Ind Fern J. 2000;17: 77-91.

260 [5] Sarker SK, Hossain AE. Pteridophytes of greater Mymensingh district of Bangladesh used as 261 vegetables and medicines. Bangladesh J Plant Tax. 2009;16(1): 47-56.

262 [6] Uddin SB, Rahman MA, Uddin MG, Pasha MK. Ethno-botancial uses of Pteridophyte from 263 Chittagong Hill Tracts of Bangladesh. Nepal J Plant Sci. 2008;2(1): 89-93.

264 [7] Akomolafe GF, Rahmad Z. Taxonomic diversity of ferns of two recreational forests in 265 Kedah, Malaysia: Checklists of Ferns of Forests in Kedah, Malaysia. Mal J Sci. 2019: 1-11.

266 [8] Bedawi SH, Go R, Mustafa M. New records of terrestrial pteridophytes in Genting 267 Highlands, Pahang, Malaysia. Pert J Trop Agri Sci. 2009;32(2): 169-74. 
268 [9] Akinsoji A, Agboola OO, Adeonipekun PA, Oyebanji OO, Adeniyi TA, Ajibode MO.

269 Occurrence and distribution of Pteridophytes in parts of Lagos and Osun states. Ife J Sci.

$270 \quad 2016 ; 18(2): 447-53$.

271 [10] Akomolafe GF, Sulaimon A. Taxonomic survey of occurrence, diversity and ethnobotany of

272 Pteridophytes in some parts of Nasarawa State, Nigeria. Fern Gaz. 2018;20(7): 269-79.

273 [11] Addo-Fordjour P, Rahmad ZB. Liana assemblages in tropical forests of Africa and

274 Southeast Asia: diversity, abundance, distribution and management. In: Parthasarathy N, editor.

275 Biodiversity of Lianas: Sustainable Development and Biodiversity. Switzerland: Springer, 2015.

276 pp. 81-98.

277 [12] Malhi Y, Wright J. Spatial patterns and recent trends in the climate of tropical rainforest

278 regions. Phil Trans R Soc B. 2004;359(1443): 311-29.

279 [13] Lewis SL, Sonké B, Sunderland T, Begne SK, Lopez-Gonzalez G, Van Der Heijden GM, et

280 al. Above-ground biomass and structure of 260 African tropical forests. Phil Trans R Soc B.

$281 \quad 2013 ; 368(1625): 20120295$.

282 [14] Addo-Fordjour P, Rahmad ZB, Burnham RJ. Intercontinental comparison of liana 283 community assemblages in tropical forests of Ghana and Malaysia. J Plant Ecol. 2017;10(6):

$284 \quad 883-94$.

285 [15] Oloyede FA, Odiwe AI, Olujiyan AS. Composition and distribution of vascular epiphytes in 286 different areas in Obafemi Awolowo, Nigeria. Not Sci Biol. 2014;6(3): 316-320.

287 [16] Oke SO, Isichei AO. Floristics and structure of the fallow vegetation in Ile-Ife area of 288 Southwestern Nigeria. Nig J Bot. 1997;10: 37-50.

289 [17] Rahmad ZB, Akomolafe GF. Distribution, Diversity and Abundance of Ferns in A Tropical 290 University Campus. Pertanika Journal of Tropical Agricultural Science. 2018;41(4). 
291 [18] Rahmad ZB, Addo-Fordjour P, Asyraf M, Rosely NFN. Mistletoe abundance, distribution

292 and their associations with trees along roadside in Penang, Malaysia. Trop Ecol. 2014;55(2):

$293 \quad 255-262$.

294 [19] Hussein MK. Recreational forest landscape development: A strategy for managing forest 295 resources in sustainable manner in Malaysia. J Int Sci Pub: Ecol \& Saf. 2014;8(1314-7234): 3129641.

297 [20] Parris BS, Kiew R, Chung RCK, Saw LG, Soepadmo E. Flora of Peninsular Malaysia Series

298 I: Ferns and Lycophytes 1. Malaysia: Forest Research Institute Malaysia (FRIM); 2010.

299 [21] Parris BS, Kiew R, Chung RCK, Saw LG. Flora of Peninsular Malaysia Series I: Ferns and

300 Lycophytes 2. Malaysia: Forest Research Institute Malaysia (FRIM); 2013.

301 [22] Parris BS, Kiew R, Chung RCK, Saw LG. Flora of Peninsular Malaysia. Malaysia: Forest

302 Research Institute Malaysia (FRIM); 2020.

303 [23] Chao A, Ma KH, Hsieh TC. User's guide for iNEXT online: Software for interpolation and 304 Extrapolation of species diversity. Institute of Statictics. Recuperado de 305 http://chao.stat.nthu.edu.tw/wordpress/software_download. 2016.

306 [24] Barbour M, Burk JH, Pitts WD, Gillians FS, Schwartz MW. Terrestrial ecology. Chicago, 307 Illinois: Addson Wesley Longman, Inc; 1999.

308 [25] Sathapattayanon A, Boonkerd T. Pteridophyte diversity along a gradient of disturbance 309 within mines in Thong Pha Phum District, Kanchanaburi province. BRT Res Rep. 2006;2549: 131011.

311 [26] Keerthi SS, Shevade SK, Bhattacharyya C, Murthy KR. Improvements to Platt's SMO 312 algorithm for SVM classifier design. Neural comp. 2001;13(3): 637-49. 
313 [27] Jones NA, Ross H, Lynam T, Perez P, Leitch A. Mental models: an interdisciplinary

314 synthesis of theory and methods. Ecol \& Soc. 2011;16(1).

315 [28] Zelazowski P, Malhi Y, Huntingford C, Sitch S, Fisher JB. Changes in the potential

316 distribution of humid tropical forests on a warmer planet. Phil Trans R Soc A. 2011;369: 137-60.

317 


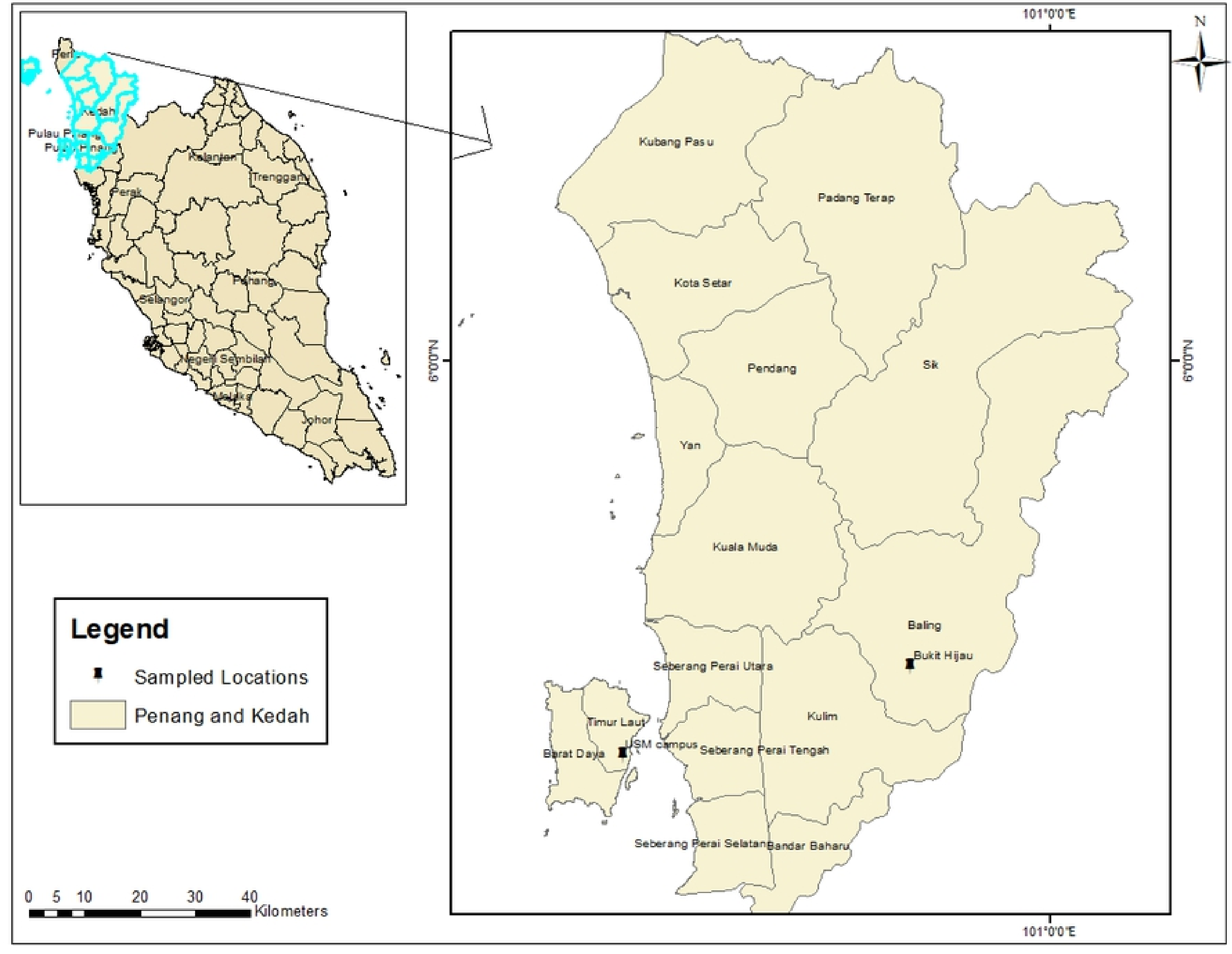

Fig1 


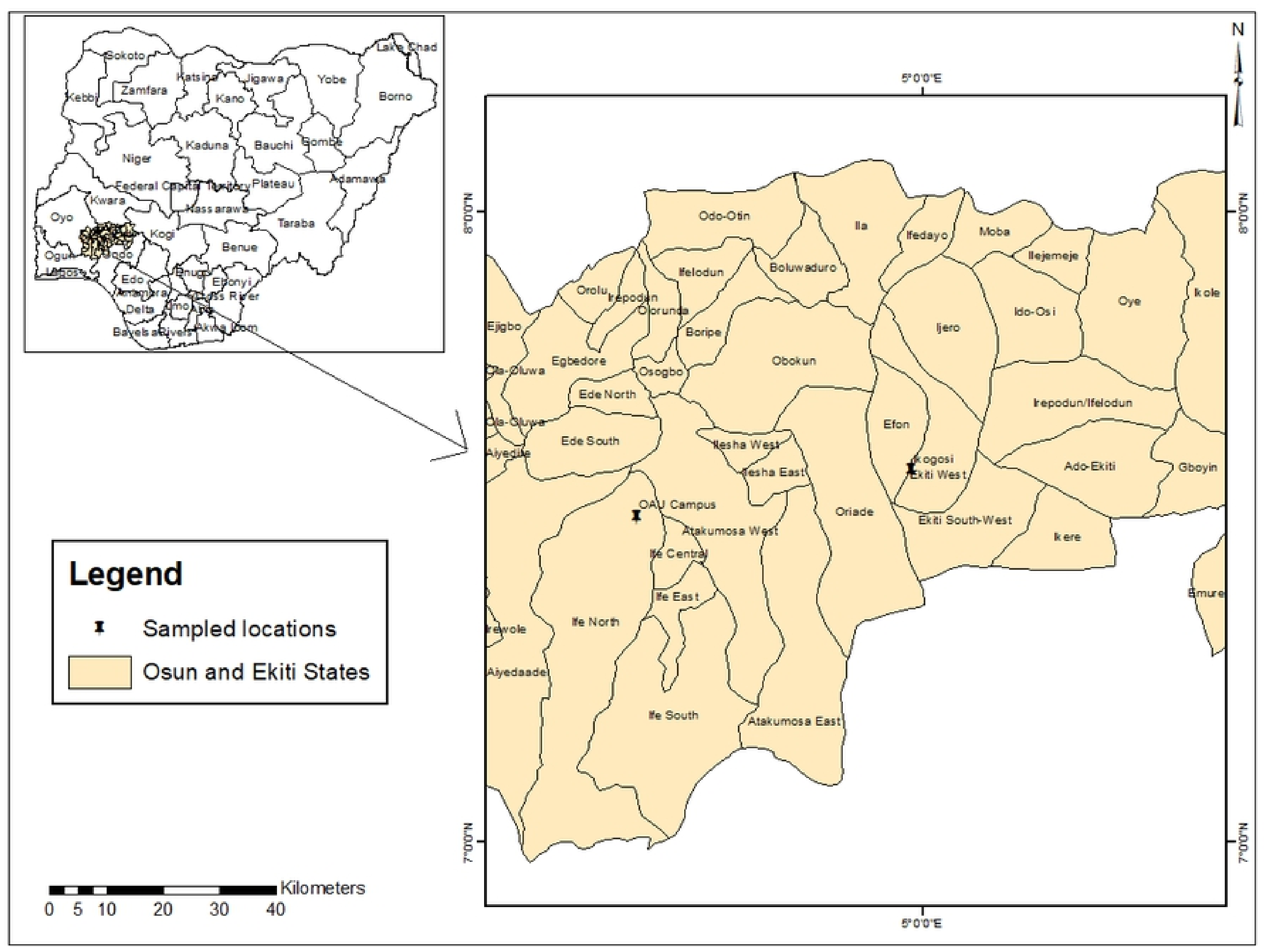

Fig 2 
Number of individuals

$\square$ Malaysia -- Nigeria

- Nigeria

— interpolated - -.' extrapolated

Fig $3 a$ 


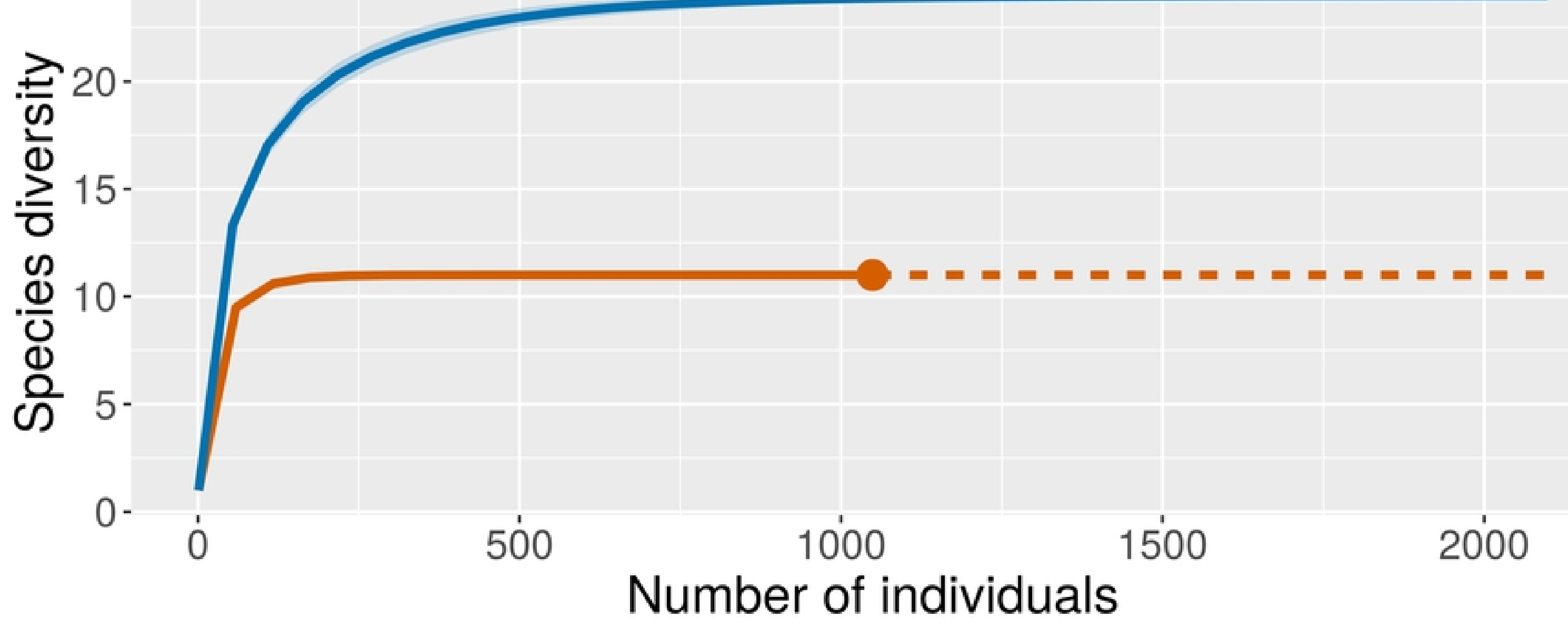

- interpolated - - extrapolated

- Ikogosi

$-\mathrm{C}$ Ikogosi $\mathrm{-O}$ OAUCampus

Fig 3c 
Non-metric MDS

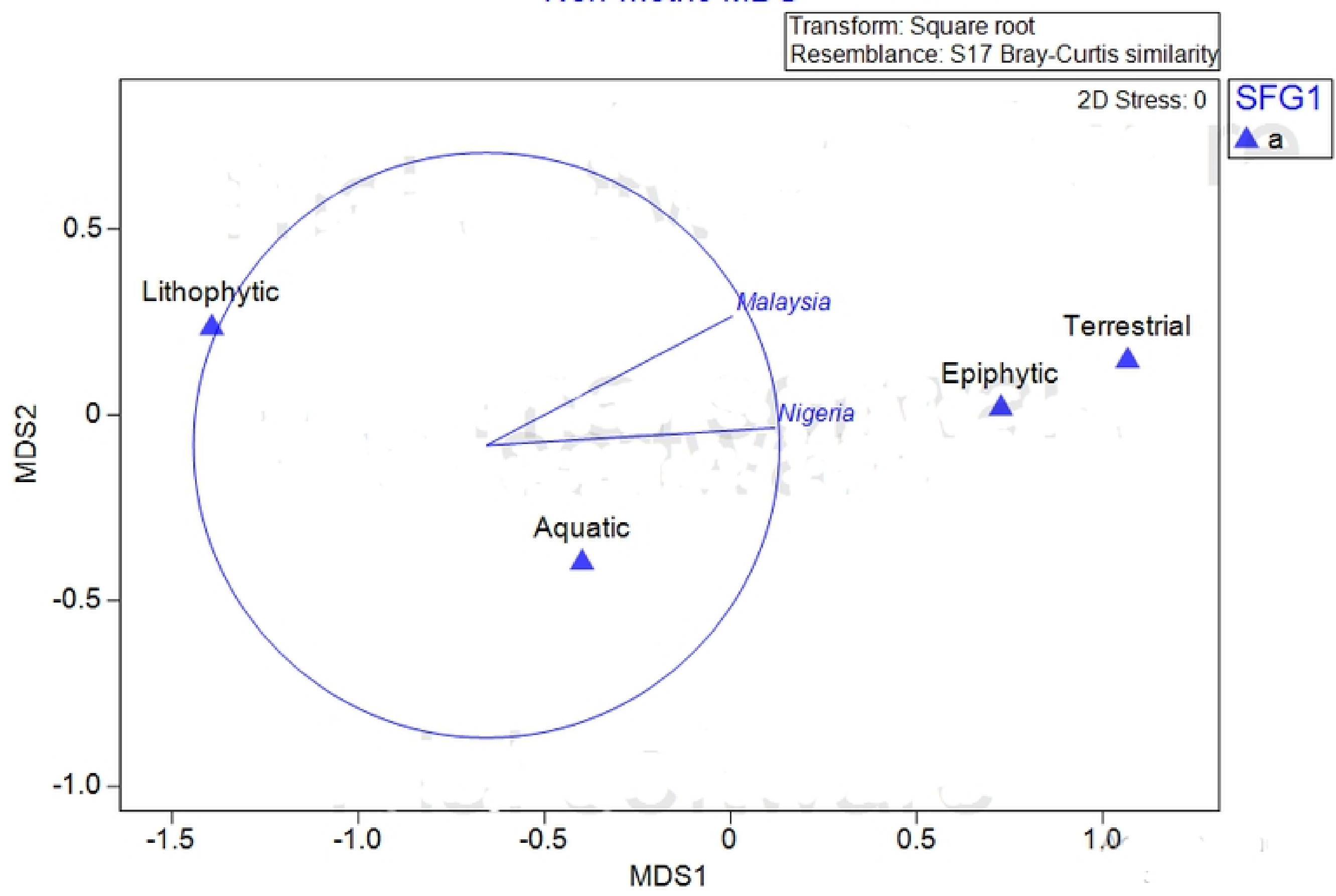

Fig 4 


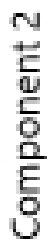

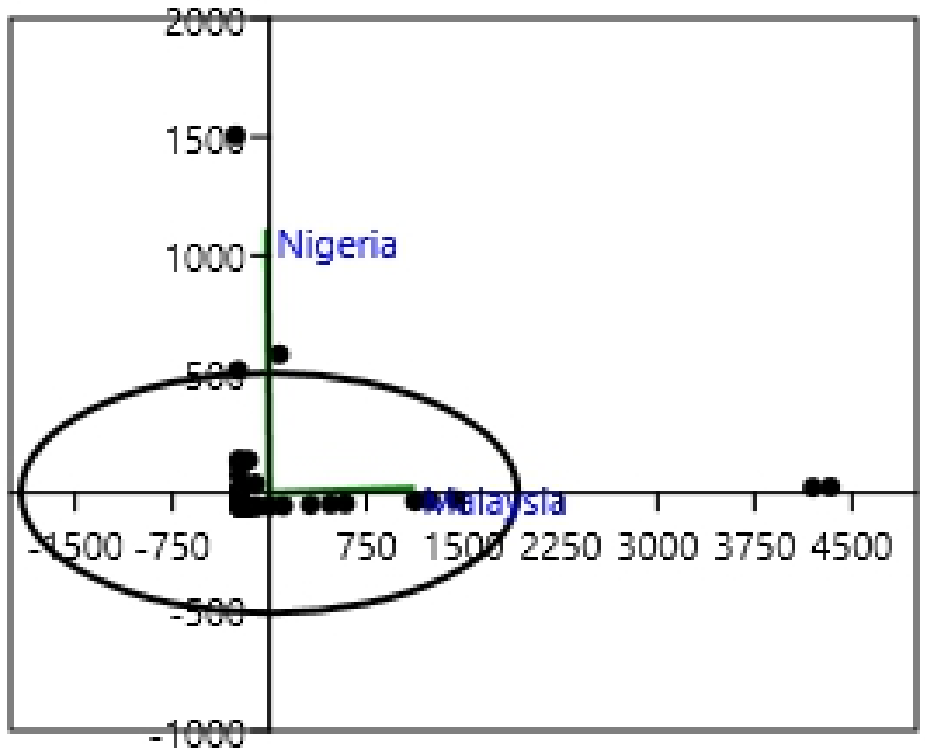

Component 1 